\begin{abstract}
Iranica
Abstracta Iranica Revue bibliographique pour le domaine irano-aryen

Volume 32-33 | 2013

Comptes rendus des publications de 2009-2010
\end{abstract}

\title{
John M. Smith. Hülegü Moves West: High Living and Heartbreak on the Road to Baghdad
}

\section{Denise Aigle}

\section{(2) OpenEdition}

1 Journals

\section{Édition électronique}

URL : http://journals.openedition.org/abstractairanica/40609

DOI : 10.4000/abstractairanica.40609

ISSN : 1961-960X

Éditeur :

CNRS (UMR 7528 Mondes iraniens et indiens), Éditions de l'IFRI

\section{Édition imprimée}

Date de publication : 1 décembre 2013

ISSN : 0240-8910

\section{Référence électronique}

Denise Aigle, « John M. Smith. Hülegü Moves West: High Living and Heartbreak on the Road to Baghdad", Abstracta Iranica [En ligne], Volume 32-33 | 2013, document 230, mis en ligne le 01 juillet 2016,

consulté le 03 octobre 2020. URL : http://journals.openedition.org/abstractairanica/40609; DOI https://doi.org/10.4000/abstractairanica.40609

Ce document a été généré automatiquement le 3 octobre 2020.

Tous droits réservés 


\title{
John M. Smith. Hülegü Moves West: High Living and Heartbreak on the Road to Baghdad
}

\author{
Denise Aigle
}

\section{RÉFÉRENCE}

John M. Smith. « Hülegü Moves West: High Living and Heartbreak on the Road to Baghdad », in : L. Komaroff, ed., Beyond the Legacy of Genghis Khan. Leyde, Brill, 2006, p. 111-134.

1 John M. Smith nous offre, à la suite de ses nombreuses publications sur l'histoire militaire mongole, une étude détaillée de cette campagne de Hülegü. Il apporte, de manière convaincante, une nouvelle vision de la progression mongole en direction de Bagdad. Selon l'A., les soldats mongols n'étaient pas accompagnés dans cette campagne par leurs familles et leurs troupeaux.

\section{AUTEURS}

DENISE AIGLE

EPHE, Paris 